\title{
DERLEME
}

\section{Ülkemizdeki Palyatif Bakım Modeli ve Ölçüm Araçlarının Kullanımının Değerlendirilmesi Merve ÇELIKK ${ }^{1}$ Ayşsegül KOÇ²}

\section{ÖZ}

Dünya nüfusunun giderek yaşlanması, kronik hastalıklardaki artış palyatif bakıma olan ihtiyacı arttırmıştır. Palyatif bakımın amacı, ağrı ve diğer semptomların giderilmesi, hafifletilmesi, hasta birey ve bakım verenlerinin bireysel ihtiyaçlarına göre gereksinimin karşılanması ve yaşam kalitesinin arttırılmasıdır. Ciddi hastalıkla baş eden hasta birey ve bakım verenlerinin sıkıntılarının giderilmesi profesyonel sağlık ekibinin önemli sorumluluğudur. Birey, hastalık tanısını alır almaz başlayan palyatif bakım hizmeti boyunca sağlık ekibinin, hasta birey ve ailesine destek olması, bütüncül bakış açısı ile kapsamlı bir şekilde değerlendirip iyilik hallerini sürdürmelerini desteklemesi beklenmektedir. Ölüm sonrası yas sürecinde bakım verenlerin sıkıntılarının giderilmesi ile palyatif bakım hizmeti devam etmektedir. Palyatif bakım ekibinin üyeleri, bakım ve tedavinin istenilen düzeyde olması için palyatif bakım hakkında nitelikli olmalıdır. Eğitim ve klinik deneyimin önemli olduğu palyatif bakım alanında, sağlık profesyonellerinin palyatif bakım hakkında bilgilerinin geçerli ve güvenilir ölçüm araçları ile değerlendirilmesi palyatif bakımın kalitesini arttıracaktır. Palyatif bakım bilgisini değerlendiren ölçüm araçlarının sayısı artmakla beraber ülkemizde palyatif bakım bilgisini ölçmeye yönelik sınırlı, geçerli ve güvenilir ölçüm araçlarına rastlanmaktadır.

Anahtar Kelimeler: Geçerlilik; Güvenilirlilik; Hemşirelik; Palyatif bakım; Öğrenci

\section{Evaluation of Palliative Care Model and Use of Measurement Tools in Our Country Merve ÇELIKK ${ }^{1}$ Ayşegül KOÇ}

\begin{abstract}
The aging of the world population and the increase in chronic diseases have increased the need for palliative care. The aim of palliative care is to relieve and alleviate pain and other symptoms, to meet the needs of the patient and their caregivers according to their individual needs and to increase the quality of life. It is the important responsibility of the professional health team to eliminate the problems of patients and caregivers who are coping with a serious illness. During the palliative care service, which starts as soon as the individual is diagnosed with the disease, it is expected that the healthcare team will support the patient and their families, evaluate them comprehensively with a holistic perspective and support them to maintain their well-being. Palliative care service continues with the elimination of the problems of caregivers during the post-death mourning process. Members of the palliative care team must be qualified about palliative care so that care and treatment are at the desired level. In the field of palliative care, where education and clinical experience are important, evaluating the knowledge of health professionals about palliative care with valid and reliable measurement tools will increase the quality of palliative care. Although the number of measurement tools evaluating palliative care information is increasing, there are limited, valid and reliable measurement tools to measure palliative care information in our country.
\end{abstract}

Keywords: Nursing; Palliative care; Student; Reliability; Validity

${ }^{1}$ Hacettepe Üniversitesi Tıp Fakültesi Onkoloji Hastanesi, (Medikal Onkoloji Kliniği), Ankara, Türkiye.

${ }^{2}$ Ankara Yıldırım Beyazıt Üniversitesi, Ankara, Türkiye.

Sorumlu Yazar: Merve ÇELIK

E-posta adresi: merveee465@gmail.com

Gönderi Tarihi: 30.06 .2021

No: 0000-0003-3667-0738

Kabul Tarihi: 18.11 .2021 


\section{GíRiș}

\section{Problemin Tanımı ve Önemi}

Dünya nüfusunun giderek yaşlanması, kronik hastalıkların giderek artmasına sebep olmakta ve küresel anlamda palyatif bakım hizmetine olan ihtiyacı ve önemi arttırmaktadır.

Palyatif bakım; psikolojik, sosyal ve spiritüel bakım hizmet desteği içeren, ağrı ve diğer hastalık semptomlarının kontrol edilmesini amaçlayan, ilerleyici, ciddi hastalığa sahip bireylerin aktif ve bütüncül bakımı sonucu bireylerin yaşam kalitesinin arttırılmasını hedeflemektedir (1).

Palyatif bakım; hastaya özgü tanılama, planlama, girişimler, izlem gibi klinik yeterlilik ve düzenli bir süreci kapsamaktadır. Palyatif bakım süreci, hasta tanısını alır almaz başlamakta ve ölüme kadar iyileşmeyi amaçlayan tedavi ve bakım ile devam etmektedir. Ölüm sonrası yas sürecinde hastaya bireyin yakınlarını destekleyen bakım ile sonlanmaktadır (2).

Hasta birey ve bakım verenleri ile en çok iletişim içinde olan hemşirelerin, palyatif bakım sürecinde eğitim, koordinasyon, savunuculuk, bakım ve liderlik gibi önemli sorumlulukları vardır. Hemşire, hasta ve bakım verenlerinin bireyselliğini göz önünde bulundurarak palyatif bakım hizmeti vermekle yükümlüdür $(1,3,4)$.

Hemşirelerin, palyatif bakım hizmeti hakkında bilgi düzeyinin yüksek olması, bakımın kalitesini artırmakta, multidisipliner ekip içerisinde aktif roller üstlenmesini sağlamaktadır.

Palyatif bakım sürecindeki bilgi eksikliği, etkili palyatif bakım hizmetinin önemli engelleri arasındadır (3). Günümüzde artan palyatif bakım hizmeti ihtiyacına ek olarak eğitimli, deneyimli sağlık profesyonelleri ihtiyacı da artmaktadır. Palyatif bakım hizmeti multidisipliner bir ekip yaklaşımıyla yürütülmelidir. Eğitimli ve deneyimli sağlik profesyonellerinden oluşan bu ekipte rol alan bütün sağlık profesyonellerinin yeterli eğitim alarak palyatif bakım hakkında bilinçlenmesi çok önemlidir (3).

Dünyada, palyatif bakım hizmetinde görevli sağlık profesyonellerinin palyatif bakım hususunda bilgi düzeylerinin ölçülmesi ve ölçüm sonucunda ortaya çıkan bilgi eksikliklerinin giderilmesi palyatif bakım hizmetinin niteliğini arttıracaktır. $\mathrm{Bu}$ durumda, geçerli ve güvenilir palyatif bakım bilgi ölçeklerinin önemi ortaya çıkmaktadır. 
Ülkemizde, geçerli ve güvenilir olan palyatif bakım

bilgisini ölçen çok sınırlı çalışmalar bulunmaktadır

(5). Bundan dolayı, palyatif bakım bilincinin gelişmesi ve palyatif bakım hizmetinin kalitesinin artması için, bilgi düzeyinin belirlenmesi amacıyla yeterli ölçüm araçlarına gereksinim vardır.

\section{Palyatif Bakım Tanımı}

Türk Dil Kurumu, palyatif kelimesini “Tedavi edici etkisi olmayan, ağrı ve sızıları geçici olarak hafifleten ve dindiren (ilaç vb.)" şeklinde tanımlamıştır (3, 6). Latinceden köken alan "Pallative (Palliare)" koruyucu ya da kapsayıc1 anlamındadır. İngilizce terminolojide "Palliative" terimi hafifletici, yatıştırıcı, geçici çare anlamında kullanılmaktadır $(1,4)$.

Dünya Sağlık Örgütü (DSÖ) tarafından Palyatif Bakım kavramı, ilk kez 1986 yılında "Tedavi edici yaklaşımların tükendiği, son dönem hastalara sunulan bir sağlık hizmeti." olarak tanımlanmıştır. Bu tanımın kapsamı genişletilerek 2002 yılında, palyatif bakım hastalarının tanısını aldığ 1 andan itibaren başlayarak yas sürecinde bakım veren ailenin desteklenmesi ile devam etmesi gerektiği belirtilmiştir. Yetişkinler için yapılan güncel tanıma göre palyatif bakım; "Yaşamı tehdit eden bir hastalığa sahip hasta ve bakım verenlerinin başta ağrı, fiziksel, psikososyal ve ruhsal sorunlarının erken tespiti, etkili değerlendirilmesi ve tedavi edilmesiyle önlenmesi veya giderilmesi ile yaşam kalitesini arttıran bir yaklaşım." olarak tanımlamıştır (7-9).

Avrupa Palyatif Bakım Birliği, palyatif bakımı; "küratif (tam iyileşmeyi hedefleyen tedavi) tedaviye yanıt vermeyen hastaların bütüncül bakımıdır. Palyatif bakım yaklaşımı disiplinler arasıdır ve hastane, bakımevi ve toplum dahil her yerde mevcut olmalıdır. Palyatif bakım, ölmeyi normal bir süreç olarak görür; ölümü ne hızlandırır ne de erteler ve ölüme kadar mümkün olan en iyi yaşam kalitesini korumak için hizmet sunar." şeklinde belirtmiştir (10).

Amerikan Hospis ve Palyatif Bakım Organizasyonu, palyatif bakımın odak noktasını; "genellikle tedavi edici bakıma ek olarak, ciddi hastalıkların ağrısına, semptomlarına ve stresine odaklanır.', şeklinde ifade etmiştir (11).

\section{Palyatif Bakımın Amacı ve Kapsamı}

Palyatif bakım bir bakım felsefesidir. Aile üyelerini de kapsayan organize bir yaklaşımdır. Amaç, 
yaşamı ve ölümü olağan sürecinde ilerleterek yaşam kalitesini arttırmaktır. Ne ölümü hızlandırır ne de yaşamı uzatmaktadır (1).

Palyatif bakımın odağında hasta otonomisi bulunmaktadır. Hasta bireyin, bireysel seçimlerine göre yapılandırılmış bir yaşam kalitesi sağlanması gerekmektedir. $\mathrm{Bu}$ nedenle hasta birey ve bakım verenlerinin, değer ve inançları, tercihleri, beklentileri dikkate alınarak ileri destek hizmet anlayışı benimsenip, sağlanmalıdır $(1,3)$.

Hospis ve palyatif bakım kuruluşlarının iş birliği ile ilk baskısı 2004 yılında yayınlanan, Kaliteli Palyatif Bakım Iç̧in Klinik Uygulama Kılavuzu'na göre; palyatif bakımın ciddi hastalığın her aşamasında, tedavilerle birlikte uygulanması gerektiğini, hasta bireyin ve bakım verenlerinin ihtiyaçlarına göre hizmet verilmesi gerektiğini vurgulamıştır (11).

DSÖ’ye göre palyatif bakım; ciddi hastalıklarla ilişkili problemlerle karşılaşan hasta bireylerin ve bakım verenlerinin acı ve diğer sıkıntı veren sorunlarının önlenmesi ve giderilmesi olarak tanımlamaktadır. $\mathrm{Bu}$ sıkıntılar; hasta bireylerin fiziksel, ruhsal, sosyal problemleri ile bakım verenlerinin psikososyal ve ruhsal problemlerini içermektedir. Palyatif bakım, bütün bu sorunların erken tanılanmasını ve bütüncül değerlendirmesini ve etkin tedavisini gerektirmektedir. Hasta bireyin yeterli rahatlık düzeyine ulaşmak için gerekli olan her türlü tedavi ve bakım hizmetini içinde barındırmaktadır. Temelden başlayarak ileri düzey palyatif bakım eğitimi becerisine sahip sağlık bakım sistemlerinin tüm basamaklarındaki sağlık profesyonelleri tarafindan palyatif bakım hizmeti uygulanmaktadır. Palyatif bakım sadece ölmekte olan hasta için değil, tanısı ne olursa olsun ciddi hastalık sonucunda acı çeken her hasta bireyi kapsamaktadır. Palyatif bakım acıyı ve ağrıyı hafifletmekle kalmayıp, sıkıntı veren sorunları öngörüp, önlemektedir (7-9).

Hasta bireyleri, iyi ve huzurlu ölüme hazırlama, ölüm sonrası dönemde ise bakım verenlerinin ihtiyaçlarını karşılamak için profesyonel ekip yaklaşımı gerekmektedir $(1,7,8)$.

\section{Palyatif Bakımın Bileşenleri}

Birçok ciddi hastalık (kanser, kardivasküler, serobrovasküler, solunum hastalıkları, HIV/AIDS ve diyabet) palyatif bakı hizmeti gerektirmektedir. Bu bakım hizmeti, hastalığın tanı anından başlayarak ölümden sonra bakım 
verenlerin desteklenmesi ile devam etmektedir (1, 7-9).

- Temel amaç ağrı ve diğer semptomlar ile hastalığın ve tedavilerin neden olduğu birçok sorunun önlenmesi ve yok edilmesidir. Semptom kontrolü sağlanamadığında, hasta birey ve bakım verenlerinin tedaviye uyumu azalmaktadır. Tedavinin bırakılması, tedavinin sonlandırılması, bakım verilmesinde zorlanılması gibi olumsuz durumlara neden olabilmektedir $(1,7-9,12)$.

- Yaşam kalitesinin olumsuz etkilendiği ciddi, kronik hastalıklardaki tüm yaş gruplarında olan bireylere hizmet verir. Hastalık tanısı ne olursa olsun tüm bireyler uygun ilkeler ile herkesin ulaşabileceği bir hizmet olmalıdır $(1,12,13)$.

- Hasta tanısını alır almaz başlar ölümden sonra aile bireylerinin yas sürecinde desteklenmesi ile devam etmelidir. Tüm bu süreçte, bireylerin kültürel değerleri, inançları, yaşam tarzları göz önünde bulundurularak sorunlara çözüm bulunması amaçlanmaktadır $(1,12,13)$.

- Hasta birey ve bakım verenlerine özgü sorunlara göre bakım hizmeti verilmeli bu sürece bireylerin katılımı sağlanmalıdır. Hasta bireyin kendi kendine karar vermesi mümkün olmadığı durumlarda bakım verenleri ile iş birliği içinde olunmalıdır (1, $7,9,12)$

- Palyatif bakım hizmetinin sürdürülmesinde multidisipliner ekip yaklaşımı gereklidir. Farklı yaklaşımlar sadece tedavi ve bakımın sürdürülmesi değil var olan etik sorunların çözülmesine katk1 sağlamaktadır. İş birliği, etkin iletişim ve koordinasyon sayesinde ortaya çıkan problemlere karşı alınabilecek hızlı kararlar ile palyatif bakım hizmetine üst düzeyde katkı sağlanmaktadır $(1,12$, 13).

- Hasta birey odaklı iletişim, erken palyatif bakım hizmetinin anahtarıdır. Gerek hasta birey ve ailesi ile gerekse ekip içerisinde etkili iletim sağlanmalıdır. Doğru değerlendirme ve sorunların tespiti etkili iletişim ile sağlanabilmektedir $(1,12$, 13).

Palyatif bakım, sadece klinik değerlendirme değil, ekonomik destek, psikolojik destek, dini yardım gibi hizmetleri de kapsamaktadır. $\mathrm{Bu}$ bütüncül yaklaşım içerisinde hemşire, hekim, sosyal hizmet uzmanı, psikolog, diyetisyen, din görevlileri gibi birçok farklı meslek grubunu barındırır. Hasta birey ve bakım verenlerinin bütün sorunları her yönden değerlendirilmelidir $(1,12,13,15,16)$. 


\section{Dünya'da Palyatif Bakım}

Bulaşıcı olmayan hastalıklar (BOH) her yıl 41 milyon insanın ölümüne neden olmaktadır. $\mathrm{Bu}$ da dünya çapındaki tüm ölümlerin \% 71'ine denk gelmektedir. Tüm BOH ölümlerinin \% 77'si düşük ve orta gelirli ülkelerde görülmektedir. BOH ölüm nedenlerinin çoğunu kardiyovasküler hastalıklar (17.9 milyon/ \% 44), kanserler (9.0 milyon/\%22), solunum hastalıkları (3.8. milyon/\%9) ve diyabet (1.6 milyon) oluşturmaktadır. Bu hastalık grupları, BOH kaynaklanan ölümlerin \%80'inden fazlasını oluşturmaktadır $(7,8)$.

DSÖ’nün global sağlık tahminlerinde 2017 yılında

Dünya genelinde yaklaşık 59,945 milyon ölüm olmuştur. Bu ölümlerin \% 73.4'ü bulaşıcı olmayan hastalıklar, \%14.6'sı bulaşıcı hastalıklar, \%4'ü gebelik ve doğum öncesi sıkıntılar, beslenmeyle ilgili sıkıntılar, \%8'i yaralanmalar, zehirlenmeler vb. nedenlerle gerçekleşmiştir. Palyatif bakım hizmetlerinin odak noktası $\mathrm{BOH}$ oluşmuşsa da, ilaca dirençli tüberküloz ve HIV/ AIDS gibi başka kronik hastalıkları da kapsamaktadır (9).

Küresel olarak, tüm yaş gruplarında palyatif bakım hizmetine ihtiyacı olan kişi sayısı 56 milyonun üzerindedir. Tüm ölümlerin $\% 45,3$ 'ü de palyatif bakım hizmetine ihtiyacı vardır. Palyatif bakıma ihtiyaç duyan hastaların yaklaşık \% 40'ı 70 yaş ve üstü iken, \%27'si 50-69 yaş arasında, yaklaşık \%26'sı ise 20-49 yaş arasındadır. Sadece \%7'si 017 yaş grubunu oluşturmaktadır (9).

Palyatif bakım hizmeti ihtiyacı olan yetişkinlerin (20 yaş ve üzeri) büyük çoğunluğunu kanserli bireyler (\%28.2), \%22.2'si HIV/AIDS'li bireyler, $\%$ 14.1'i serebrovasküler hastalıklara sahip bireyler ve \%12.2'si demanslı bireyler oluşturmaktadır (7, 9).

Her yıl 40 milyon insanın palyatif bakıma muhtaç olduğu öngörülmektedir. Dünya çapında, palyatif bakım hizmetine ihtiyacı olan kişilerin yaklaşık \%14'ü palyatif bakım hizmetinden faydalanmaktadır. DSÖ’nün 2019 yılında 194 ülkede yaptığı bulaşıcı olmayan hastalıklarla ilgili çalışmada, bu ülkelerin \%68'inde palyatif bakım için ekonomik destek mevcut olduğu ve ülkelerin sadece $\% 40 ' 1$ palyatif bakım hizmetine ihtiyacı olan hastaların en az yarısına ulaşabildiği bildirilmiştir (9).

Düşük gelirli ülkeler, yüksek gelirli ülkelere göre hastalıkları önleme, teşhis tedavi, bakım, sosyal desteğe, birçok farklı uzmana ve uzman hizmetlere 
daha az erişime sahiptirler. Palyatif bakımın

evrensel olarak ulaşılabilir olması çok önemlidir.

Palyatif bakım hizmetlerinin planlanması ve

uygulanması, sıkıntı veren problemlerin

kapsamının değerlendirilmesine dayanmakta ve

palyatif bakım hizmetlerinin birey merkezli

olmasının önemini ortaya koymaktadır. DSÖ’ye göre, palyatif bakım bir seçenek değil, tıbbi ve etik bir zorunluluktur ve sağl1k sistemlerinin tüm seviyelerinde ihtiyacı olan herkes tarafindan erişilebilir olmalıdır $(7,8,17)$.

\section{Türkiye'de Palyatif Bakım}

Ülkemiz sağlı mevzuatında palyatif bakım ilk olarak; 11.4.1928 tarihli ve 1219 sayılı Tababet ve Şuabatı San'atlarının Tarzı İcrasına Dair Kanun, 5.7.1987 tarihli ve 3359 sayılı Sağlık Hizmetleri Temel Kanun ve 13.12.1983 tarihli ve 181 sayılı Sağlık Bakanlığının Teşkilat ve Görevleri Hakkında Kanun Hükmünde Kararname'ye dayanılarak hazırlanan, 10.03.2005 tarih ve 25751 sayılı Resmî Gazete'de yayımlanan "Evde Bakım
Hizmetleri Sunumu Hakkında Yönetmelik” ile uygulamaya konulmuştur (18).

Daha sonra, 01.02.2010 tarihinde ve 389520 sayılı Makam Oluru ile yürürlüğe konulan "Sağlık Bakanlığı'nca Sunulan Evde Sağlık Hizmetlerinin Uygulanma Usul ve Esasları Hakkında Yönerge" hazırlanmıştır (19).

Palyatif Bakım Hizmetlerinin Uygulama Usul ve Esasları Hakkında Yönerge, 09.10.2014 tarihinde yürürlüğe girmiştir (20). Bu yönerge ile palyatif bakım daha kapsamlı ve verimli uygulanabilir hizmet haline getirilmiştir.

Sosyal Güvenlik Kurumu Sağlı Uygulama Tebliğine 24.12.2014 tarihinde yayınlanan ekleme ile 'Palyatif bakım tedavisi, Sağlık Bakanlığı'nca palyatif bakım verme konusunda tescil edilmiş olan Sağlık Bakanlığı'na bağlı yataklı sağlık tesislerince faturalandırılır." Açıklaması eklenerek palyatif bakım hizmetleri ödeme kapsamına alınmıştır (21). Palyatif bakım merkezleri, 09.08.2015 tarihinde 29440 sayılı Resmî Gazete'de yayımlanan "Türkiye Kamu Hastaneleri Kurumuna Bağlı Sağlık Tesislerinde Görevli Personele Ek Ödeme Yapılmasına Dair Yönetmelikte Değişiklik Yapılması Hakkında Yönetmelik” ile 01.09.2015 
tarihinden sonra özellikli birimler/kurumlar arasına alınmıştır. $\mathrm{Bu}$ yönetmelik ile palyatif bakım hizmetlerinde görev alan personelin ilave ödeme alabilmeleri sağlanmıştır (22).

Sağlık Bakanlığg'nın öncesinde palyatif bakım ile ilgili çalışmaları yokken, Kanserle Savaş Dairesi Başkanlığı tarafından palyatif bakımı da kapsayan 2009-2015 Ulusal Kanser Kontrol Programı yayınlanmıştır. Palya-Türk projesi, 2010 yılında başlamış ve böylece palyatif bakım hizmet birimlerinin kurulması hız kazanmıştır $(23,12)$.

Projede, evde sağlık hizmetleri ve aile hekimlerinin beraber yürüteceği hastane temelli bakıma ihtiyaç duymadan çözülmesi hedeflenen toplum temelli palyatif bakım hizmetleri belirlenmiştir $(12,23)$. Proje kapsamında amaç ülkemize en uygun olan palyatif bakım modeli geliştirmektir (12).

Türkiye'de Palya-Türk projesinde ana başlıklar;

- Opioid erişilebilirliğinin arttırılması

- Toplum tabanlı palyatif bakım modelinin hayata geçirilmesi şeklindedir $(12,21)$.

Türk Onkoloji Vakfı'nın 1993-1997 y1lları arasında İstanbul'da kurduğu "Kanser Bakımevi" palyatif bakım hastalarına hizmet veren ilk kuruluştur $(15,23)$.
Sağlık Bakanlığg'na bağlı, Dr. Abdurrahman Yurtaslan Ankara Onkoloji ve Eğitim Araştırma Hastanesi bünyesinde ilk palyatif bakım merkezi 2007 yılında hizmet vermeye başlamıştır. Ülkemizde, erişkin hastalara kapsamlı bakım veren ilk palyatif bakım merkezi 2012 yılında Ankara Ulus Devlet Hastanesi'nde açılmıştır (15, 23).

\section{Palyatif Bakım Hizmetinin Uygulanmasında}

\section{Önemli Engeller}

- Dünyada çoğu ülke palyatif bakım hizmetlerini yeterince desteklememekte, ülkelerdeki palyatif bakım hizmeti kanun ve tüzüklerde oldukça farklılıklar görülmektedir (17). Palyatif bakımı destekleyen politikaların yetersiz olması palyatif bakım hizmetinin yetersiz sunulmasına neden olmaktadır $(9,17)$.

- Giderek artan palyatif bakım ihtiyacı doğrultusunda, bu hizmeti veren eğitimli palyatif bakım ekip üyelerinin yeterli sayıda olması gerekmektedir. Palyatif bakım hizmeti özel bilgi, tutum ve davranış gerektirmektedir $(7,8,17,24)$. 
- Bundan dolayı, palyatif bakım ekibinin profesyonel üyeleri için eğitim ve deneyim önemlidir. Dünya çapındaki sağlık çalışanlarının büyük çoğunluğunun palyatif bakım ilkeleri ve uygulamaları hakkında bilgisi yetersizdir (17).

- Eğitimin yetersiz olması, palyatif bakım hizmetinin ne zaman başlanması gerektiğini, semptom yönetimini, hasta birey ve ailesinin bilgi eksikliklerinin giderilmesini, ölüm sürecinde baş etmenin sağlanmasını olumsuz yönde etkilemektedir $(9,17)$.

- Ağrı kontrolü için, opioid ilaçlara erişim dünya çapında büyük bir sorun oluşturmaktadır (26). DSÖ'nün ağrı için temel ilaçlar model listesindeki ilaçların çoğu, özellikle opioidler, kaliteli palyatif bakım hizmetinin sağlanması için gereklidir (17).

\section{Palyatif Bakım Hemșireliği}

Palyatif bakım sadece hastalığı değil, insanı bütüncül olarak ele alan, merkezinde hasta birey olan, bireyselleştirilmiş bir bakım modelidir. Uluslararası Hemşireler Konseyi (ICN), hemşirelerin ölmekte olan hasta birey ve bakım verenlerine karşı rolünü; acının hafifletilmesi, hastanın fiziksel, psikososyal, kültürel ve spiritüel ihtiyaçlarının belirlenmesi, ağrının erken tespiti, değerlendirilmesi ve yönetimi, hasta ve ailesinin yaşam kalitesini yükseltme olarak bildirmiştir (25). ICN'e göre (2012), hemşirelerin palyatif bakım hizmeti sürecinde bakım sağlama konusunda bilgili ve yetenekli olma sorumluluğu bulunmaktadır ve hemşirenin rollerini palyatif bakım hizmetinin temeli olarak belirtmiştir (25).

Hemşireler, yedi gün 24 saat, ciddi hastalık sürecinin tüm basamaklarında hasta merkezli bakımda önemli rol oynamaktadır. Temel nokta, kaliteli palyatif bakım hizmeti sunabilmek için, hastalık ve bakım verme durumuna ilişkin değişkenlerin hasta ve yakınları üzerindeki etkileri belirlenerek, ölüm anına kadar devam ettirilmelidir. Ölüm sonrasında yaşanan yas sürecinde aileye destek sağlayarak bakıma devam edilmelidir. Böylece gerekli hemşirelik girişimlerini planlanarak yaşam kalitesini yükseltilmesi hedeflenmektedir $(1,12,13)$.

Ölüme yaklaşmakta olan hastaya sunulan bakım; dil, din, ırk ve kültürel yapısı, dini düşüncesi, hastalık tanısı ne olursa olsun barışçıl ve onurlu 
ölüme katkıda bulunabilecek nitelikte olmalı ve bu

ilke palyatif bakım süreci boyunca unutulmamalidir $(12,26)$.

Palyatif bakım hizmeti, profesyonel sağlık ekibi tarafından sunulan destekleyici bir yaklaşımdır. Palyatif bakım hemşireleri, hasta bireyin yaşamının son zamanına kadar etkin, etkili bakım ve kaliteli ölümü sağlamada bakım verici, danışman, bakım koordinatörü, eğitici, yönetim ve liderlik gibi önemli rol ve sorumluluklar düşmektedir. Bu rol ve sorumluluklar yerine getirilirken hemşire, hasta birey ve ailesinin bireysel durumu göz ard1 etmemelidir $(1,16,26)$.

Türkiye'de 04 Şubat 2014 tarihli Resmi Gazete'de yayımlanan, Sağlık Bakanlığı Sertifikalı Eğitim Yönetmeliği kapsamında, palyatif bakım sertifikalı eğitim alanı olarak belirlenmiştir. 9 Ekim 2014 tarihli 2014.5407.1970/610 Sağlık Hizmetleri Genel Müdürlüğü, Palyatif Bakım Hizmetlerinin Uygulama Usul ve Esasları Hakkında Yönerge kapsamında Palyatif Bakım Hemşireliği Sertifikalı Eğitim Programı başlatılmıştır (27).

$\mathrm{Bu}$ kapsamda ilk olarak İzmir Katip Çelebi Üniversitesi Palyatif Bakım Hemşireliği Sertifika Programı düzenlenmiştir (28).
Türkiye göz önünde bulundurulduğunda palyatif bakım konusu genelde iç hastalıkları hemşireliği dersi kapsamında verilmektedir (1). Lisans eğitimi sırasında verilen bu bilgiler mezuniyet sonrasında palyatif bakım kliniklerinde bakım ve hizmet sağlamak için yetersiz kalmaktadır $(1,26)$.

Palyatif bakım bilgisini ölçen geçerliliği ve güvenirliliği test edilmiş uygun çok az ölçek vardır.

Davis ve ark (2020), lisans hemşirelik öğrencileri için geliştirdiği Lisans Hemşireliği Palyatif Bakım Bilgi Anketi (UNPCKS) çalışmasında temel palyatif bilgisinin önemin öğrenciler için gerekliliğine vurgu yapmıştır (29). Shimizu ve ark. (2016), evde kanser hastalarına palyatif bakım sağlayan hemşirelerin tutum ve bilgilerini değerlendirmek için geliştirdiği ölçekte hemşireler için kaliteli palyatif bakım için palyatif bakım bilgisinin değerlendirilmesi üzerinde durmuştur (30). Türkiye'de palyatif bakım bilginin ölçülmesine yönelik çalışmalar oldukça sınırlıdır. Seven (2015) çalışmasında, sağlık profesyonellerinin palyatif bakım bilgi düzeylerinin, ölmekte olan hastaya bakım vermeye ilişkin tutumlarının palyatif bakımın kalitesini etkileyeceğini belirtmiştir. Ülkemizde, hemşirelere 
özgü kullanılabilecek, Seven (2015)'in yapmış olduğu Palyatif Bakım Bilgi Testi'nin dışında değerlendirme ölçeğine ulaşılamamıştır (5).

\section{SONUÇ}

Türkiye göz önünde bulundurulduğunda palyatif bakım konusu genelde iç hastalıkları hemşireliği dersi kapsamında verilmektedir (1). Lisans eğitimi sirasında verilen bu bilgiler mezuniyet sonrasında palyatif bakım kliniklerinde bakım ve hizmet sağlamak için yetersiz kalmaktadır $(1,26)$.

Palyatif bakım bilgisini ölçen geçerliliği ve güvenirliliği test edilmiş uygun çok az ölçek vardır (29, 30, 31). Seven (2015) çalışmasında, sağlık profesyonellerinin palyatif bakım bilgi düzeylerinin, ölmekte olan hastaya bakım vermeye ilişkin tutumlarının palyatif bakımın kalitesini etkileyeceğini belirtmiştir. Ülkemizde, hemşirelere özgü kullanılabilecek, Seven (2015)'in yapmış olduğu Palyatif Bakım Bilgi Testi'nin dışında değerlendirme ölçeğine ulaşılamamıştır (5). Bundan dolayı, geçerli ve güvenilir ölçüm araçlarına ve palyatif bakım bilgisinin belirlenmesine yönelik daha fazla kanıt temelli araştırmalara gerek olduğu düşünülmektedir.

\section{KAYNAKLAR}

1. Fadıloğlu Ç. Kanserde Palyatif Bakım. Can G (editör). Onkoloji Hemşireliği, 2. Baskı, Ankara. Nobel Tıp Kitapevleri; 2019. s. 1157-1175.

2. Şahan Uslu F, Terzioğlu F. Dünyada ve Türkiye'de palyatif bakım eğitim ve örgütlenmesi. Cumhuriyet Hem Der. 2015; 4(2):81-90.

3. Ulusoy S. Hemşirelerin Palyatif Bakıma Yönelik Bilgi Ve Tutumları, Sağlık Bilimleri Enstitüsü, Evde Bakım Hemşireliği Anabilim Dalı, Yüksek Lisans Tezi, Samsun: Ondokuz Mayıs Üniversitesi, 2019.

4. Sarman A. Palyatif/pediatrik palyatif bakımın tarihsel gelişim süreci, ilkeleri ve hemşirelik bakımı. BAUN Sağ Bil Derg. 2019; 8(3):153-160.

5. Seven A. Hemşirelerin Palyatif Bakım Hakkındaki Bilgi Düzeyleri ve Ölmekte Olan Hasta Bakımına İlişkin Tutumları, Sağlık Bilimleri Enstitüsü, Hemşirelik Anabilim Dalı, Yüksek Lisans Tezi, Sakarya: Sakarya Üniversitesi, 2015.

6. Türk Dil Kurumu. Türk dil kurumu sözlükleri [Internet]._ [cited 2021 Mar 14] Available from: https://sozluk.gov.tr/.

7. World Health Organization. Pallative Care [Internet]. [cited 2021 Mar 23]. Available from: https://www.who.int/newsroom/fact-sheets/detail/palliative-care.1.

8. The World Health Organization-World wide Palliative Care Alliance [Internet]. Global Atlas of Palliative Care at the End of Life. [cited 2021 Mar 10]. Available from: https://www.who.int/nmh/Global_Atlas_of_Palliative_Care.p df.

9. The World Health Organization-World wide Palliative Care Alliance

[Internet]. Global Atlas of Pallative Care 2nd Edition. [cited 2021 Mar 10]. Available from: http://www.thewhpca.org/resources/global-atlas-on-end-oflife-care.1.

10. European Association of Palliative Care [Internet]. What is Palliative Care? [cited 2021 Mar 10]. Available from: https://www.eapcnet.eu/about-us/what-we-do/.

11. National Hospice and Pallative Care Organization. Explanation of pallative care [Internet]. [cited 2021 Mar 15]. Available from: https://www.nhpco.org/palliative-careoverview/explanation-of-palliative-care/.

12. Koç O. Türkiye'de Palyatif Bakım. Aksakal N, Kahveci K, Koç O (editörler). Palyatif Bakım Hemşireliği El Kitabı, 1. Baskı. Ankara. Akademisyen Kitapevi; 2018. s. 9-15.

13. Fadıloğlu Ç. Palyatif Bakım. Yıldırım Y, Fadıloğlu Ç (editörler). Palyatif Bakım Semptom Yönetimi ve Yaşam Sonu Bakım, 1. Baskı. Ankara. Nobel Tıp Kitapevleri; 2017 s. 1-37.

14. Boyraz G. Yenidoğan Palyatif Bakım Tutum Ölçeğinin Türkçeye Uyarlanması ve Web Tabanlı Palyatif Bakım Eğitiminin Etkinliğinin Değerlendirilmesi, Gülhane Sağlı Bilimleri Enstitüsü, Hemşirelik Anabilim Dalı, Doktora Tezi, Ankara: Sağlık Bilimleri Üniversitesi, 2019.

15. Saygılı M. Üç Farklı Palyatif Bakım Hizmet Modelinin Kanserli Hasta- Hastaya Bakım Veren Aile Üyeleri Açısından Değerlendirilmesi ve Maliyet- Etkililik Analizi, Sosyal Bilimler Enstitüsü, Sağlık Yönetimi Anabilim Dalı, Doktora Tezi, Ankara: Hacettepe Üniversitesi, 2016.

16. Çıtıl R, Okan İ, Önder Y, Çeltek NY, Süren M, Bulut YE. Tıp fakültesi öğrencilerinin palyatif bakım konusundaki farkındalıklarının değerlendirilmesi. Bezmialem Science. 2018; do1: $10.14235 /$ bs.2018.1582.

17. World Health Organization [Internet]. Integrating palliative care and symptom relief into primary healthcare: a WHO guide for planners, implementersand managers. [cited 2021 Apr 12]. Available from: 
https://apps.who.int/iris/bitstream/handle/10665/274559/9789 241514477eng.pdf?ua $=1$.

18. Evde Bakım Hizmetleri Sunumu Hakkında Yönetmelik, T.C. Resmi Gazete, say1: 2575, 10 Mar 2005.

19. Sağlık Bakanlığınca Sunulan Evde Sağlık Hizmetlerinin Uygulama Usul ve Esasları Hakkında Yönerge, T.C. Resmi Gazete, Say1: 389520, 01 Feb 2010.

20. Palyatif Bakım Hizmetlerinin Uygulama Usul ve Esasları Hakkında Yönerge, T.C. Resmi Gazete, Sayı: 15722819/840, 7 Jul 2015

21. Sosyal Güvenlik Kurumu Sağlık Uygulama Tebliğinde Değişiklik Yapılmasına Dair Tebliğ, T.C. Resmi Gazete, sayı: 29215, 24 Sep 2014.

22. Türkiye Kamu Hastaneleri Kurumuna Bağlı Sağlık Tesislerinde Görevli Personele Ek Ödeme Yapılmasına Dair Yönetmelikte Değişiklik Yapılması Hakkında Yönetmelik, T.C. Resmi Gazete, sayı: 29440, 9 Agus 2015.

23. Şencan İ, Keskinkılıç B, Gültekin M, Karaca AS, Öztürk C, Boztaş G, Karaca M Z, Utku EŞ, Hacıkamiloğlu E, Turan H, Dede İ, Dündar S. (editörler). Türkiye Kanser Kontrol Programı, 1. Bask1. Ankara. Sağlık Bakanlığı Türkiye Halk Sağlığı Kurumu Kanser Daire Başkanlığı; 2016. s. 62-65.

24. Kahveci C, Gökçınar D. Knowledge about pallative care in the families of patients. Acta Medica. 2014: 30:1370- 1372.

25. International Council of Nurses [Internet]. Nurses' role in providing care to dying patient sand their families. [cited 2021 Feb 7]. Available from: https://www.icn.ch/sites/default/files/inlinefiles/A12_Nurses_ Role_Care_Dying_Patients.pdf.

26. Elçigil A. Palyatif bakım hemşireliği. GülhaneTıpDerg. 2012; doi:10.5455/gulhane.30582.

27. T.C. Sağlık Bakanlı̆̆ı. Sağlık alanı sertifikalı eğitim standartları. Palyatif bakım hemşireliği. [cited 2021 Apr 15]. Available from: https://shgmesdb.saglik.gov.tr/Eklenti/4074/0/palyatif-bakhems-sep-standartlaripdf.pdf.

28. Kamu Hastaneleri Genel Müdürlüğü [Internet]. Palyatif Bakım Hemşireliği Sertifikalı Eğitim Programı Uygulama Yetkisi Alan Sağlık Tesisleri. [cited 2021 Apr 7]. Available from: https://khgmsaglikbakimdb.saglik.gov.tr/TR,44162/9-palyatifbakim-hemsireligi sertifikali-egitim-programi-uygulamayetkisi-alan-saglik-tesisleri.html. 2.

29. Davis A, Lippe M, Burduli E, Leiker BC. Development of a new under graduate palliative care knowledge measure. J Prof Nurs. 2020; doi.org/10.1016/j.

30. Shimizu M, Nishimura M, Ishii Y, Kuramochi M, Kakuta N, Miyashita M. Development and validation of scales for attitudes, self-reported practices, difficulties and knowledge among home care nurses providing palliative care. Eur J Oncol Nurs. 2016; doi.org/10.1016/j.ejon.2016.02.009.

31. Şencan H. Sosyal ve Davranışsal ölçümlerde güvenilirlik ve geçerlilik, 1. Baskı. Ankara. Seçkin Yayıncılık; 2005. s. 160.

32. Kozlov E, Carpenter BD, Rodebaugh TL. Development and validation of the palliative care knowledge scale (PaCKS). Palliat Support Care. 2016; doi:10.1017/S1478951516000997.

33. R Core Team R: A language and environment for statistical computing [Internet]. R Foundation for Statistical Computing, Vienna, Austria. [cited 2021 Apr 15]. Available from: https://www.R-project.org/.

34. Rosseel, Y. Lavaan: An R package for structural equation modeling and more. Version0.5-12 (BETA). J Stat Softw. 2012; 48(2):1-36.

35. Davis LL. Instrument review: getting the most from a panel of experts. Appl Nurs Res. 1992; 5:194-197.

36. Mulaik SA, James LR, Van Alstine, J, Bennett N, Lind, S, Stilwell, CD. Evaluation of goodness-of-fit indices for structural equation models. 1989; https://doi.org/10.1037/00332909.105.3.430.

37. Canbolat Ö, Özkal F. Palyatif bakım dersi alan ve almayan hemşirelik ögrrencilerinin palyatif bakıma yönelik düşünceleri. JGEHES. 2019; 1(1):27-39.

38. Özveren H, Kırca K, Gülnar E, Güneş NB. Palyatif bakım dersinin öğrencilerin palyatif bakıma ilişkin bilgisine etkisi. G.O.P. Taksim E.A.H. JAREN. 2018; 4(2):100-10.

39. Gültekin A, Özdemir A, Kavak F. Hemşirelik öğrencilerinin palyatif bakımla ilgili görüşleri. 5. Uluslararası evde sağlık ve sosyal hizmetler kongresi, Antalya, 2018; 61-66.

40. Karkada S, Nayak B, Nayak M.G. Awareness of palliative care among diploma nursing students. Indian J Palliat Care. 2011; 17(1):20-23.

41. Al Qadire M. Knowledge of palliative care: an online survey. Nurse Educ Today. 2014; 34(5):714-718.

42. Esin MN. Veri toplama yöntem ve Araçları ve veri toplama araçların güvenirlik ve geçerliği İçinde: Erdoğan S, Nahçivan $\mathrm{N}$, Esin MN (editörler). Hemşirelikte araştırma, 3. Bask1, Ankara. Nobel Tip Kitapevleri; 2018. s. 195-220. 